\section{Historia mówiona jako hermeneutyka losu. Doświadczenie przedtekstowe}

Piotr Filipkowski

TEKSTY DRUGIE 2018, NR 1, S. 40-60

DOI: $10.18318 /$ td.2018.1.3

\section{Wprowadzenie teoretyczne}

Wszystkie słowa w tytule brzmią znajomo. Od bardzo dawna albo zupełnie niedawna krążą przecież swobodnie w językowym obiegu. Niektóre tylko w akademickim, inne także, może przede wszystkim, w potocznym. Co jednak znaczy takie ich nieoczywiste zestawienie? Czy to opis, diagnoza czy raczej postulat? I czy w ogóle ma sens, skoro przy minimum uważności widać tu różne napięcia, jeśli nie sprzeczności? Nie sposób ich jednak rozwikłać inaczej, jak wydobywając te znaczenia składowych i takie ich wzajemne relacje, które całość uczynią zrozumiałą, sensowną i może ważną.

Zróbmy więc krok wstecz, by wstępnie uzgodnić rozumienie znajomych słów i fraz. Historię mówioną pod swą nazwą znamy krótko, ale nie ma wątpliwości, że chodzi o rejestrowanie w formie dźwiękowej, niekiedy także wizualnej, opowieści ludzi o ich przeszłych doświadczeniach i przeżyciach, a potem tych opowieści dalsze interpretowanie - archiwizowanie, spisywanie,
NARODOWY PROGRAM ROZWOJU HUMANISTYKI

Niniejszy tekst powstał w ramach projektu Archiwum Danych /akościowych przy IFISPAN, finansowanego przez Ministerstwo Nauki i Szkolnictwa Wyższego w ramach Narodowego Programu Rozwoju Humanistyki - NPRH (grant nr 0027/NPRH2/H11/81/2012).

Piotr Filipkowski

- socjolog, adiunkt w Instytucie Filozofii i Socjologii PAN, członek Zespołu Socjologii i Antropologii Kultury. W 2008 roku obronił doktorat w Szkole Nauk Społecznych przy IFiS PAN na temat doświadczenia obozu koncentracyjnego w perspektywie biograficzno-narracyjnej (Historia mówiona i wojna. Doświadczenie obozu koncentracyjnego w perspektywie narracji biograficznych, 2010). Analizuje doświadczenia, pamięci i narracje autobiograficzne w różnych kontekstach empirycznych i teoretycznych. 
analizowanie i wykorzystywanie jako źródeł historycznych albo danych socjologicznych czy antropologicznych. $Z$ rozmysłem piszę o interpretowaniu jako nadrzędnej kategorii scalającej wszystkie dalsze praktyki związane z tymi zapisami. Oczywiście sam akt zapisu też jest interpretacją - wyborem, niekoniecznie wyłącznym i nie zawsze do końca uświadomionym, sposobu obcowania z doświadczeniem, z pamięcią, z narracją. Za tymi interpretacjami stoi w historii mówionej jednak coś jeszcze - sytuacja spotkania dwojga (najczęściej) ludzi, zawiązana albo chociaż zadzierzgnięta na chwilę, między nimi relacja i będąca jej częścią rozmowa. Ta rozmowa jest zwykle ukierunkowana i przechylona w jedną z jej stron, ku jednej osobie, ale skrywa jakiś głębszy międzyludzki dialog. Albo tylko, może tak najczęściej, jego próbę, jego potencjalność.

Cząstką elementarną tak rozumianej historii mówionej - a nie jest to przecież rozumienie specjalnie nowe, a jedynie nieznacznie przeakcentowane - jest doświadczenie spotkania, a nie jego produkt końcowy, w postaci świadectwa audio/wizualnego czy jego tekstowego zapisu, nie mówiąc już o opartych na nich historycznych, socjologicznych, antropologicznych artykułach i monografiach.

Przeakcentowanie historii mówionej, jakie tu proponuję, chociaż nie zaskakujące, ma, może mieć, istotne konsekwencje. I praktyczne, i teoretyczne. O pierwszych trudno w tym miejscu pisać, ponieważ są indywidualnym doświadczeniem każdego (prawie każdego? większości? a może tylko niektórych?... - to nieistotne), kto uważnie i wrażliwie praktykuje historię mówioną. Jej cząstki elementarne wbudowują się nieraz trwale w materię własnego świata. Zmienia się wówczas jego obraz - zmienia się odbity w nich obraz siebie.

Pomówmy jednak o konsekwencjach teoretycznych. Główny problem (w) historii mówionej, tzn. w tym, co się o niej w kontekście akademickim mówi i pisze, to nadal problem wiarygodności jej świadectw. Z pola nauk historycznych zdominowanych przecież przez tradycyjne, tzn. modernistyczne, tj. „prawdziwościowe” rozumienie historii (i historiografii) słychać stale ten sam zarzut, to samo pytanie: o (historyczną) prawdę mówionego świadectwa. A bywa, że już i tego pytania nie słychać, tylko obiegowy slogan, że ktoś kłamie, jak naoczny świadek. Trudno się temu dziwić - krytyka źródeł na tym wszak polega, by krytycznie wątpić w prawdziwość źródeł (jak to w praktyce wygląda w przypadku innych ich typów, zwłaszcza dokumentów, tak często absolutyzowanych w wojnach o historyczną prawdę - to osobna sprawa). A indywidualna pamięć - zawsze niepełna i fragmentaryczna, nieraz przy 
tym chwiejna, zmienna i podatna na zewnętrzne wpływy - jest łatwym celem ataku. Bo jak przekonująco wykazać, że w opowieści „świadka historii” zawarta jest historyczna prawda (o) przeszłości? Bez elementarnej, niekoniecznie bezkrytycznej, w nią (dobrej) wiary trudno to zrobić.

A jednak historia mówiona znalazła i nadal znajduje swoje miejsce, gdzieś na pograniczu badań historycznych i analiz pamięci - zarówno zbiorowej, jak i indywidualnej (zakładając, że to rozróżnienie daje się utrzymać). Też w muzeach, w projektach wystawienniczych i edukacyjnych, oraz w wielu innych praktykach kulturowych. Ta obecność ma dziś więc wiele odsłon, dla których szukać można różnych uzasadnień. W badaniach historycznych tych tradycyjnych, gdzie chodzi (rzekomo) o przeszłość samą, a nie np. zmagania z jej reprezentacją, z jej pamięcią, z narracją o niej, obecna jest - mam wrażenie - na dwa podstawowe sposoby.

Po pierwsze, jako historia oddolna. Ludzie w dominującej większości pozostają w historii bezimienni. Odnotowani w urzędowych dokumentach - między, włącznie, świadectwem urodzenia i aktem zgonu - istnieją dla historii (dla historiografii) przeważnie bezpodmiotowo. Historia mówiona chce to zmienić - i zmienia w dostępnej sobie skali. To zawsze, niemal od początku, było jej mocne uzasadnienie. W tym jej oddolnym paradygmacie powstały ważne prace - wśród nich klasyczna, programowa, wielokrotnie wznawiana i tłumaczona na kilka języków książka Paula Thompsona The Voice of the Past. Oral History ${ }^{1}$ No właśnie - w tytule mamy tu wyraźną deklarację metodologiczną. I ontologiczną. Chociaż nagrywamy wywiady w teraźniejszości, tu i teraz - to, spełniwszy pewne warunki, możemy zarejestrować głos przeszłości, doświadczenie z tam i wtedy. Nie da się tego zrobić bez dobrej wiary, bez minimum zaufania do ludzi i ich opowieści o ich życiu i ich świecie. To „ich” jest tu kluczowe - chodzi bowiem o to, by te małe, oddolne prawdy włączyć do „dużej”, ,wysokiej”, a więc produkowanej akademicko prawdy historycznej. Nie ma to nic wspólnego ze sztuką naiwną. Thompson jest świadomy ryzyka, jakie podejmuje, i zarzutów, z jakimi taka „pozytywistyczna” historia mówiona może się spotkać. W swojej książce uprzedza je i dość przekonująco rozbraja - na gruncie klasycznej krytyki źródeł. Pokazuje, że historia mówiona pozwala na wytworzenie nowych źródeł. Jeśli nie lepszych, to w niczym nie gorszych od tych zastanych w archiwach.

1 Ostatnie wydanie angielskie: Oxford University Press 2000. 
Ale historii mówionej zorientowanej na przeszłe doświadczenia rozmówców - powiedzmy więc: klasycznej² - daje się bronić jeszcze inaczej: jako historii słabszych, wykluczonych, pominiętych. Tych bez głosu - którym należy, zupełnie dosłownie, głos przywrócić. Albo inaczej - ich głos prywatny zamienić w głos historyczny, a więc publiczny. Tu podstawowy argument nie jest metodologiczny, lecz etyczny - a za nim polityczny. Nie chodzi tylko o wytworzenie nowych źródeł, o więcej historii (more history), lecz o źródła jakościowo inne, nowe, które, zinterpretowane i przełożone na historyczne narracje, odmienią utrwalone, dominujące obrazy przeszłości.

Obie strategie - historiograficznej „normalizacji” źródeł historii mówionej i ich etyczno-politycznego dowartościowania świetnie się uzupełniają (stąd „lewicowość” zachodniej oral history). To połączenie dawało i nadal daje napęd wielu projektom badawczym historii mówionej jako historii oddolnej, alternatywnej, historii wykluczonych i pominiętych, które poszerzają, komplikują, problematyzują, a na pewno pluralizują nasze opowieści i wyobrażenia o przeszłości. Mowa o historii, ale dotyczy to przecież nauk społecznych w ogólności - przynajmniej ich wariantów biograficznych, humanistycznych, doświadczeniowych, fenomenologicznych, egzystencjalnych...

I jeszcze jeden nurt, osobny, który roboczo nazywam holokaustową historią mówioną. Ma on swoją odrębną historię - rzadko uwzględnianą przy szkicowaniu historii oral history - zapoczątkowaną pierwszymi świadectwami obozowych ocaleńców, rejestrowanymi w formie dźwiękowej zaraz po wojnie. Mam na myśli spektakularne przedsięwzięcie amerykańskiego psychologa Davida Bodera z Chicago, który z ciężkim i wielkim sprzętem - gdyż tego wymagała ówczesna technologia zapisu dźwięku - objechał w 1946 roku kilka obozów dla dipisów na terenie wyzwolonych Niemiec, rejestrując wywiady z byłymi więźniami. Dopiero przed kilku laty materiał ten został opracowany i udostępniony w przeznaczonym dla niego archiwum internetowym: Voices of the Holocaust (http://voices.iit.edu/). Nie sposób tu szerzej pisać o tym, co działo się (albo nie wydarzyło się) w międzyczasie - czyli o kilku powojennych dekadach znikomej obecności Zagłady (także) w historii mówionej, a potem rosnącej popularności i skali projektów jej poświęconych, aż po globalny projekt dokumentacyjny Visual History Archive zainicjowany przez Stevena Spielberga, w którym zarejestrowano ponad 52 tysiące wywiadów

2 Za nieklasyczne uznałbym więc te podejścia, które historii mówionej nie stawiają żadnych pytań historycznych, skupiając się wyłącznie na analizach pamięci, narracji czy sytuacji wywiadu - na jej tu i teraz 
wideo, oraz po inspirowane nim, ale i wobec niego krytyczne, europejskie przedsięwzięcia akademickie, jak Mauthausen Survivors Documentation Project czy International Forced Labourers Documentation Project ${ }^{3}$.Wskazuję na odrębność tego nurtu nie tylko i nie głównie ze względu na historyczną wyjątkowość doświadczenia Zagłady (wszak mamy tu też np. nieżydowskie świadectwa obozowe), ale przede wszystkim ze względu na egzystencjalny ciężar wielu zarejestrowanych w nim świadectw. Problemy teoretyczne, metodologiczne i etyczne, jakie towarzyszą ich rejestrowaniu i interpretowaniu, nie są tu zupełnie inne czy nowe - ale bywają wyostrzone, niekiedy radykalnie. Warto więc ten nurt historii mówionej traktować jako jej przypadek graniczny, a poczynione w jej ramach, nieraz wnikliwe rozpoznania powikłanych związków doświadczeń, pamięci i narracji - z ich pęknięciami i zakłóceniami $^{4}$ - uczyć się przenosić na inne ludzkie historie. Historycznie inne, ale egzystencjalnie - i narracyjnie - niekiedy podobne, podobnie graniczne.

Mamy pobieżną i podręczną mapę historii mówionej. Jak ją teraz odczytać jako hermeneutykę losu? I jak dalej - i czy w ogóle się da? - wydobywać z niej doświadczenie przedtekstowe? Nie są to łatwe zadania. Pierwsza trudność już w tym, że hermeneutykę kojarzymy przecież niemal intuicyjnie z interpretacją tekstów. A jeśli nie tekstów, to ludzkich „dzieł”: a więc wytworów w pewien sposób zamkniętych, skończonych, a z pewnością zastanych, osadzonych w tradycji i historii, chociaż zawsze otwartych, w tym sedno hermeneutyki, na interpretację. Można tu protestować, że redukuję hermeneutykę do jej przedfilozoficznych, a w każdym razie przedheideggerowskich początków, sprowadzając do sztuki interpretacji tekstów - najpierw biblijnych, potem świeckich, względnie „rozumiejącej” metodologii nauk humanistycznych w stylu Diltheya. Bo przecież hermeneutyka pojęta mocniej, ontologicznie, jak u Gadamera, to nasz ludzki sposób bycia w świecie - czyli tego świata całościowego (a nie tylko metodycznego, naukowego) rozumienia ${ }^{5}$. Tak, zgoda, i do takiej mocnej hermeneutyki chciałbym tu właśnie - choć rzadko

3 Zarys tej historii z odesłaniami do dalszych lektur zawiera mój tekst: Pozagładowe historie mówione: nagrania, archiwa, sposoby lektury, "Zagłada Żydów. Studia i Materiały” 2013 nr 9.

L.L. Langer Świadectwa Zagłady. Wrumowisku pamięci, przeł. M. Szuster, ŻlH, Warszawa 2015.

To ultrakrótkie przywołanie różnych wariantów hermeneutyki wymagałoby rozwinięcia, na które nie ma tutaj miejsca. Odesłać więc muszę do kompetentnego wykładu jej dziejów i wcieleń: P. Dybel Oblicza hermeneutyki, Universitas, Kraków 2012. Fundamentalną odrębność epistemologicznego i ontologicznego rozumienia hermeneutyki wydobyła bardzo wyraźnie Elżbieta Zakrzewska-Manterys w książce Hermeneutyczne inspiracje, Oficyna Naukowa, Warszawa 1998. 
wprost - nawiązywać. Niemniej i ona, jak widzimy choćby z pobieżnego przeglądu bibliografii prac Heideggera czy Gadamera, lubi brać na warsztat dzieła próby najwyższej, o utrwalonej i niepodważalnej renomie: dialogi Platona, wiersze Hölderlina, dramaty Goethego, poezje Rilkego... Jak daleko stąd - jak blisko, do wywiadów ze zwykłymi ludźmi, które są istotą historii mówionej?

Może nie tak daleko, chociaż środki wyrazu tak, zdaje się, odległe. Pod warunkiem wszak, że dociążymy egzystencjalny wymiar hermeneutycznego rozumienia - odciążając jej wymiar dziejowy albo wręcz rezygnując z niego; z tego wymiaru, w którym dzieła przeszłości coś ważnego nam mówią, a ściślej, coś ważnego i zawsze aktualnego podsuwają do interpretacji. Whistorii mówionej nie mówią dzieje ani dzieła, lecz zwyczajny człowiek. Zdarzyć się może, niejako przy okazji, że twórca dzieł i arcydzieł, ale ta twórczość i jej wytwory będą tu, co najwyżej, jednym z kontekstów jego wypowiedzi, być może istotnym dla jej (i ich) interpretacji. Bowiem nie za pomocą tych dzieł tutaj się wypowiada, ale za pomocą języka swojej zwykłej, codziennej komunikacji. Nie jest to język prywatny - taki nie istnieje, nie byłby wtedy językiem, co wiemy nie tylko od Wittgensteina - a jednak przybiera nieraz formy idiolektyczne, niepodrabialne, głęboko własne.

A najbardziej własne jest samo brzmienie głosu. Źródłowa oralność historii mówionej - tak mocno postulowana i tak często zatracana w transkrypcji i dalszych interpretacjach - nadaje tej praktyce szczególny rys podmiotowy. Słowo wypowiadane jest wszak zrośnięte z wypowiadającym. Nagranie dźwiękowe tego związku nie rozrywa. Nawet odsłuchiwane po latach, uobecnia narratora. Zaryzykowałbym tezę, że uobecnia mocniej niż fotografia, a może nawet mocniej niż sam obraz ruchomy, zapis filmowy. Pomyślmy: przecież dźwiękowy zapis znajomego ludzkiego głosu pozbawiony obrazu natychmiast wywołuje mówiącego w wyobraźni czy pamięci słuchacza - tymczasem niemy jego obraz, a być może zwłaszcza ruchomy, raczej go odrealnia i wyobcowuje. Chodzi tu więc o hermeneutykę słowa mówionego - i nadto wypowiadanego w konkretnej sytuacji rozmowy, spotkania, współbycia.

To współbycie, choć zadzierzgnięte w historii mówionej z powodu i wokół wypowiadanych słów, do nich się nie sprowadza. I nie chodzi tylko o to, co wszak ważne, że wpisane jest w szerszy kontekst spotkania, które angażuje gesty, ruchy, zachowania - łącznie: tworzy interakcję, a ładniej: środowisko dialogu. Chodzi też o to, że zawiera w sobie ciszę, która znaczy - a więc wymaga interpretacji. A znaczyć może np. poszukiwanie słowa - albo rezygnację 
z takich poszukiwań. Znaczyć może wolę zakrycia czegoś - albo właśnie ujawnienia, choć niewysłowionego, niedopowiedzianego. Znaczyć może krzyk rozpaczy - albo niewysłowioną radość. To tylko przykłady. Nie sposób tych znaczeń zinwentaryzować i zakodować - trzeba je każdorazowo od nowa rozpoznawać i interpretować.

Hermeneutyka jest poszukiwaniem sensu. W historii mówionej ten sens zawiera się przede wszystkim w wypowiadanych słowach oraz w ciszy między nimi. Czego jednak te słowa i ta cisza dotycza, do czego odsyłają? Najprościej: do zdarzeń z przeszłości, do minionych faktów. Albo, nieco inaczej, do przeszłych doświadczeń i przeżyć ${ }^{6}$. Fakty są jakby po stronie zewnętrznego świata - przeżycia, po wewnętrznej, podmiotowej stronie mówiącego. Z tymi faktami i doświadczeniami z przeszłości jest ciągły problem w historii mówionej. Pamięć wszak zawodzi - nawet wtedy, a może szczególnie wtedy, kiedy łudzi swoją precyzją. Język zwodzi - podsuwa struktury, schematy, formuły, frazy, żyjące niejako swoim samoistnym życiem, pozbawionym istotnego związku z rzeczywistością, którą rzekomo opisują. Strukturalizmy i poststrukturalizmy fundujące ciągle (jeszcze) znaczną część teoretycznego zaplecza współczesnej humanistyki, czerpią przecież swoje żywotne moce z tej językowej - czy szerzej: znakowej - samoistności i arbitralności. Które zawsze wymykają się rzeczywistości, uciekają przed nią i nie dają się dogonić. Albo, jeśli wolimy, bezskutecznie za tą rzeczywistością gonią. Jak to się dzieje na poziomie historycznego pisarstwa, pokazał sugestywnie Hayden White - obrazy przeszłości malują nam nie tyle historyczne fakty, co językowe struktury i gatunkowe konwencje?.

Dlaczego inaczej dziać by się miało na poziomie indywidualnej opowieści o własnej przeszłości? Tu wszak kontrola nad językiem - i sprawność w jego zastosowaniu jest z reguły niepomiernie mniejsza. Oralność, z jej natychmiastowością i nieodwołalnością, dodatkowo osłabia tę kontrolę. Można się oczywiście poprawić, wypowiedzieć coś raz jeszcze - i kolejny raz - to jednak nie znosi wcześniejszych wypowiedzi, lecz dodaje nowe, komplikując narrację. Praktyki piśmiennicze natomiast udostępniają nam z reguły swoje wersje

6 Rozumienie historii mówionej jako historii doświadczeń - odróżnialnej od historii faktów - rozwija w swoich pracach empirycznych i teoretycznych Alexander von Plato, jeden z jej głównych niemieckich przedstawicieli. Zob. tegoż Oral History als Erfahrungswissenschaft: zum Stand der mündlichen Geschichte in Deutschland „ "BIOS” 1991 Nr 4, s. 97-119.

7 Zrobił to w wielu pracach, ale w sposób najpełniejszy i najlepiej udokumentowany w głośniej: Metahistory. The Historical Imagination In Nineteenth-Century Europe, Baltimore-London 1973. 
ostatnie (niekiedy niejako wiele wersji ostatnich), skrywając drogi dojścia do nich. Ponadto pamięć zapisaną łatwiej uzgadniać z rzeczywistością - tzn. konfrontować z innymi historycznym źródłami - niż tę wypowiadaną. Skoro tak, to w jaki sposób ocalić jakikolwiek faktograficzny czy doświadczeniowy wymiar świadectwa mówionego?

W międzyludzkiej praktyce komunikacyjnej - a tym jest wyjściowo historia mówiona - łatwiej to zrobić niż w (post)strukturalistycznej teorii. Hermeneutyka podejrzeń wobec tekstu ustępuje w niej bowiem hermeneutyce zaufania wobec mówiącego o swoich doświadczeniach człowieka. (Na marginesie: może właśnie dlatego zwykle najbardziej krytyczne wobec tej metody badawczej są osoby, które nigdy jej poważnie nie praktykowały.) Oczywiście nie dzieje się tak zawsze i nie zawsze dzieje się tak w tym samym stopniu. Ale tak się nieraz zdarza. Zwłaszcza wtedy, takie jest moje wrażenie, ale też badawcze - i zwyczajnie między/ludzkie - doświadczenie, gdy ukierunkujemy tę komunikację nie na pozyskanie od rozmówcy historycznych informacji, ale przede wszystkim na wydobycie przezeń (przez nią) ich podmiotowych sensów. W historii mówionej nie chodzi bowiem tylko o prawdę - a niekiedy nawet zupełnie o nią nie chodzi (co wszak nie jest równoznaczne ze stwierdzeniem, że chodzi o rejestrację, inwentaryzację i może jeszcze weryfikację zmyśleń). Chodzić może także, a w tej propozycji przede wszystkim, o sens, jaki ludzie nadają swoim minionym doświadczeniom - zawsze w kontekście doświadczeń obecnych - i swojemu życiu jako pewnej przeżytej i poddanej refleksyjnemu oglądowi całości. I o tego sensu zakomunikowanie.

Ta całość nie jest tylko wynikiem narracyjnych czy, szerzej, kulturowych konwencji opowiadania o sobie oraz pisania biograficznych notatek i ankiet na potrzeby urzędów i innych instytucji. Chociaż te konwencje bywają w historiach mówionych rozpoznawalne i dają się samodzielnie analizować. Ale spod nich nieraz wyraźnie przebija chęć powiedzenia, czego doświadczyłem - co mnie spotkało - kim jestem. I mniej chodzi o faktograficzne detale - choć niektóre opowieści zadziwiają ich gęstością i precyzją - bardziej o umocowanie w świecie i nadanie sensów swojemu życiu. Niekoniecznie sensów dużych, całościowych, choć w wywiadach biograficznych i to nieraz się zdarza, co splotu sensów mniejszych, cząstkowych, które składają się na tę wyobrażoną życiową całość. Niczym w hermeneutycznym kole - zapamiętane i przywoływane epizody nabierają pełniejszego sensu w kontekście tej biograficznej całości. A ta całość, choć wyposażona w jakiś naddatek egzystencjalnego sensu, jest tylko konstelacją tych sensownych elementów, epizodów, wspomnień, obrazów, doświadczeń, przeżyć. 
Tak wykreślone hermeneutyczno-biograficzne koło wygląda na solidną narracyjną konstrukcję. Dość rzadko jednak taką bywa. Zwykle widzimy tylko próby zebrania rozproszonych epizodów w sensowną całość. Niektóre z tych epizodów wszak nie pasują - ale też zapomnieć i wyrzucić się nie dają. Wracają uparcie z jakimś natrętnym sensem własnym. Albo przeciwsensem, stale podkopującym albo i unicestwiającym próby domknięcia owego koła „dużego" biograficznego sensu. Paradygmatyczne są tu świadectwa obozowych i zagładowych ocaleńców - będące tyleż świadectwami rzeczywistości, którą przywołują, co - w większym nieraz stopniu - świadectwami niemożności ustabilizowania tych sensów. By to dostrzec, tzn. usłyszeć, warto obcować z ich zapisem dźwiękowym. Bez tego nie sposób uchwycić ciszy tych świadectw. A bez niej - trudno zrozumieć zapisane w nich zmagania z bez/sensem.

Ale nie samo obciążenie traumą czyni te świadectwa paradygmatycznymi. One ujawniają przecież także graniczne przypadki zmagania się człowieka z losem. I nie chodzi o los w starym stylu, o jakieś metafizyczne fatum, którego beznamiętnym i okrutnym wyrokom podlegali nawet greccy bogowie (z bogami późniejszymi sprawa jest bardziej zawiła ${ }^{8}$ ) - chociaż wyroki nieodległych nam historii, będących w zasięgu historii mówionej właśnie, a więc i historii życia jej podsądnych, bywały i nadal bywają jeszcze bardziej okrutne. Myślę tu jednak raczej o losie rozmienionym na drobne - o życiowych przypadkach, które pojawiają się jakby znikąd i uderzają punktowo, chociaż nie zawsze pojedynczo. Widziane w perspektywie autobiograficznej narracji, ukazują życie jako odpowiedź na losowe, nomen omen, przypadki.

Nie muszą to być przypadki dramatyczne i traumatyczne, które rujnują dotychczasowy porządek i sens biografii, wymagającej teraz sensu nowego - choć te bywają najbardziej wyraziste, najłatwiejsze więc też do rozpoznania. Może to być też zdarzenie, np. spotkanie innego człowieka, pozornie zwyczajne i błahe, które jednak przekroczy biograficzny próg i „przynależy oto teraz, wraz ze swoją pozytywną albo negatywną teleologią, do jedności i sensu indywidualnego losu"'.

Czy myślę to przeciw podmiotowemu sprawstwu, indywidualnej inicjatywie działania i kształtowania własnego życia? Bynajmniej. Czy przeciwko

8 Skrót dziejów fatum szkicuje Odo Marquard w błyskotliwym eseju: Koniec mocy przeznaczenia? Kilka uwag o nieuchronności tego, czym nie da się rozporządzać, w: tegoż Rozstanie z filozofiq pierwszych zasad, przeł. K. Krzemieniowa, Oficyna Naukowa, Warszawa 1994, s. 68-92.

9 G. Simmel Filozofia życia. Cztery rozdziały metafizyczne, przeł. M. Tokarzewska, Wydawnictwa IFiS PAN, Warszawa 2007, s. 109. 
strukturalnym i kulturowym (a razem, za Bourdieu: habitualnym) kontekstom biografii oraz historycznym okolicznościom, w których "to wszystko" jest zanurzone, a które przecież w znacznym stopniu, choć nigdy bez reszty, określają zarówno repertuar możliwych czy prawdopodobnych życiowych przypadków, jak i sposoby reakcji na nie - tworząc ramowe scenariusze ludzkich losów w danym miejscu i czasie. Także nie.

Wywołuję przypadek jako punkt zaczepienia dla myślenia o ludzkim życiu, jako - fundamentalnie - splocie przypadków. Nie tyle ich zastanej sumie choć nad jednym jakby nadbudowują się drugie, tworząc mniej lub bardziej spójną „biografię" - co ich usensowniającemu pod/sumowaniu w autobiograficznej opowieści. Która w historii mówionej, choć nie tylko tam, osadzona jest w bezpośrednim międzyludzkim współbyciu, w komunikowanym i przemilczanym słowie, w ciszy, w brzmieniu głosu, w wyrazie twarzy, w geście, w ruchu i bezruchu ciała. Wgląd w te wszystkie wymiary współbycia - choć nieczęsty w praktyce badawczej, a przynajmniej jej finalnych, tekstowych produktach - wyostrza kontury życiowych przypadków i ujawnia trudności albo arbitralności, ich zszycia.

Stąd krok już tylko do otwarcia perspektywy egzystencjalnej, w której nie tylko wyostrzają się życiowe przypadki - ale samo życie ufundowane jest na nieusuwalnej przygodności. Historia mówiona - nie tylko ona, to jasne, ale ona jakby w sposób elementarny i z dostępnych nam "metod badawczych" potrafi tę przygodność odsłonić i wydobyć. I nie samą przygodność, ale też człowieka, słabo-mocny podmiot, który tej przygodności daje odpór, rzutując na nią swój biograficzny sens. Nawet jeśli niezbyt oryginalny, bo przecież kulturowo czy strukturalnie predefiniowany, a przynajmniej współokreślany, to jednak, zwłaszcza gdy rzutowany jest na całe dobiegające kresu życie, jakiś głęboko własny. I tak życie, ufundowane na przygodności (za)istnienia, zbudowane z przypadków, wysłowione przygodnym językiem, zyskuje rangę indywidualnego losu ${ }^{10}$.

10 Idę tu za myślą Wiesława Myśliwskiego, który w jednym z wywiadów tak mówi o losie: „W tym znaczeniu los jest kategorią intelektualną: czy my potrafimy w życiu ukształtować naszą świadomością los. Trywializując, można by powiedzieć, że los jest zabiegiem naszego umysłu. Nie możemy się zgodzić na to, że nasze życie jest czymś przypadkowym, to byłoby zbyt ponure dla naszego istnienia. W związku z tym musimy się zdobyć na to, żeby wyeliminować w naszym życiu przypadkowość. Musimy nadać życiu rangę losu. A los sam w sobie określa, że nasze istnienie nie jest przypadkowe. Jesteśmy powołani do życia, a nie stworzeni przypadkowo" Znaleźć zdanie. Z Wiesławem Myśliwskim rozmawia Bogdan Tosza, "Znak” wrzesień 2013 nr 700, http://www.miesiecznik.znak.com.pl/7002013z-wieslawem-mysliwskim-rozmawia-bogdantoszaznalezc-zdanie/ (5.11.2017). 
Tekst, także tekst wyprowadzony ze świadectwa mówionego, ujawniający jego załamania, wyciszenia, przemilczenia - ale i przegadania, które przecież skrywają nieraz więcej niż tamte - tego losu nie odzwierciedla ani nawet nie reprezentuje. On nas na niego jedynie naprowadza. Przeczucie tego losu - i losu własnego, które możemy odbić w zwierciadle tamtego jest doświadczeniem poza-tekstowym. Tak jak pozatekstowa jest międzyludzka komunikacja fundująca historię mówioną. To „jak było”, które, mimo wszystkich trudności i tak wielu zastrzeżeń, daje się z niej czasem wyłowić i całkiem precyzyjnie zapisać, jest dla niej najpierw pre-tekstem, a potem jej tekstowym efektem ubocznym. Podstawowym jest naprowadzenie na sens. Na sens zdarzeń, doświadczeń i przeżyć - życiowych przypadków - łapanych, zawsze niedoskonale, w sieci wypowiadanych i niewypowiadanych słów. I na wyłaniający się z nich - ale je przekraczający i wstecz oświetlający - sens nadrzędny, który własną przygodność zamienia w indywidualny los. Ten sens nieczęsto bywa wprost nazwany i wysławiany - częściej jedynie przeczuty właśnie. I w tym przeczuciu zakomunikowany.

Czy historia mówiona, którą znamy z akademickiej i pozaakademickiej rzeczywistości, jest taką, jaką ją tu powyżej szkicuję? A może to jakiś nowy na nią pomysł, jakiś nowy jej projekt? To nie jest sprawozdanie ze stanu badań ani z badawczym metod. Nie jest to też jednak teoretyczny kryptomanifest. Raczej zaledwie wstępne rozpoznanie pewnej możliwości rozumienia i praktykowania historii mówionej czy nawet szerzej - prowadzenia badań opartych na wywiadach biograficzno-narracyjnych. Komplementarne wobec innych propozycji i nieuniwersalne. I to podwójnie nieuniwersalne, ponieważ ani nie dające się zastosować do każdego wywiadu, w każdym kontekście jego powstania, ani nie nadające się, czy po prostu niemożliwe do zastosowania przez wszystkich, zarówno tych praktykujących historię mówioną, jak i tych zainteresowanych końcowymi, w polu akademickim ciągle głównie tekstowymi, efektami tych praktyk.

Nie chcę idealizować historii mówionej. Komunikacja między ludźmi, która ją ustanawia, nie zawsze dobrze się układa. Nie każdy potrafi i chce się otwierać - nie każdy umie się otworzyć, nie zawsze znajduje się po temu właściwe miejsce i czas. Bywa nierzadko, że ten dialog pozostaje dosyć powierzchowny, gdy jego strony tkwią mocno w swych rolach - „badacza” $i$ „świadka historii". Bywa, że szukanie historycznych faktów - i tropienie ich zafałszowań - wypełnia całą uwagę, przesłaniając inne wymiary tej komunikacji. Ja jednak myślałem o sytuacjach innych, głębiej dialogicznych, które przecież w praktykowaniu historii mówionej także się zdarzają - a przy nieco bardziej 
otwartym nastawieniu poznawczym i nastrojeniu wrażliwości mogłyby się pewnie przydarzać częściej. Przywołuję je więc tutaj i wzmacniam teoretycznie, by wyraźniej wydobyć ten egzystencjalny moment historii mówionej. A z nim - jej humanistyczny potencjał.

\section{Rozwinięcie empiryczne}

Do Pani Stefanii trafiłem, gdyż była wielokrotną, wieloletnią uczestniczką Polskiego Badania Panelowego POLPAN"11. To socjologiczne badanie kwestionariuszowe, oparte na ogólnopolskiej próbie reprezentatywnej, realizowane cyklicznie co 5 lat - od roku 1988. Tym jednak różne od większości podobnych badań, że regularnie powracające do swoich respondentów. Moja Rozmówczyni uczestniczyła w nim sześciokrotnie - ankieter POLPAN-u odwiedził ją po raz pierwszy w 1988 roku, a potem powracał co pięć lat, zadając za każdym razem co najmniej kilkadziesiąt pytań wielostronicowego kwestionariusza dotyczących różnych aspektów jej życia - od elementarnych faktów, po opinie na rozmaite tematy, nieraz odległe od jej codziennego doświadczenia. Ostatnia taka wizyta odbyła się w 2013 roku.

Rok później zainicjowaliśmy niewielki projekt badawczy, polegający na powrocie do 21 wybranych respondentów POLPAN-u i przeprowadzeniu z nimi wywiadów biograficzno-narracyjnych ${ }^{12}$ Jednym z podstawowych celów była konfrontacja wiedzy uzyskanej z ankiet $\mathrm{z}$ daną osobą - $\mathrm{z}$ autobiograficzną narracją tej samej osoby, zarejestrowaną w swobodnym wywiadzie. Wpisywaliśmy ten wywiad w ramy socjologii biograficznej, a nie historii mówionej, ale w tym miejscu nie ma to żadnego znaczenia. Dla mnie bardzo istotny był sposób wyboru naszych rozmówców. W odróżnieniu od wszystkich znanych mi polskich badań realizowanych w paradygmacie historii mówionej czy socjologii biograficznej, trafialiśmy do osób, które drogą losową trafiły do puli respondentów badania kwestionariuszowego - w roku 1988,

11 K.M. Słomczyński z zespołem, POLPAN 1988-2013. Podstawowe informacje o Polskim Badaniu Panelowym, Warszawa: Zespół Porównawczych Analiz Nierówności Społecznych IFiS PAN (polpan.org/wp-content/uploads/2014/05/Podstawowe-informacje.pdf); strona internetowa projektu: http://polpan.org (5.11.2017).

Omówienie projektu i pierwsze próby analizy wywiadów uwzględniające wcześniejsze dane kwestionariuszowe dotyczące tych samych rozmówców/respondentów zawiera artykuł: P. Filipkowski, D. Życzyńska-Ciołek Od kwestionariuszowego badania próby losowej do pogłębionej analizy życiowych przypadków - i z powrotem. Dwa wywiady biograficzne i kilka refleksji teoretycznych, "Studia Socjologiczne" 2016 nr 3, s. 229-254. 
a potem w niej zostały ze względu na panelowy charakter badania POLPAN (nazywany nieco mylnie biograficznym). Nie były to więc osoby mające za sobą jakieś konkretne doświadczenia biograficzne czy przynależące do określonej grupy społecznej, zamieszkałe w określonym miejscu, przez kogoś polecone itd. Oczywiście i te kryteria braliśmy pod uwagę (poza ostatnim), by wybrać naszą małą „próbę” z dużej - ale ta duża, pierwotnie kilkutysięczna, była losowa. Czyli potencjalnie każdy, kto spełnił elementarne warunki brzegowe, mógł do niej trafić w roku 1988. Podkreślam ten pozornie techniczny szczegół, gdyż w perspektywie interpretacyjnej, nazwanej tutaj hermeneutyką losu, jest czymś więcej niż ciekawostką metodologiczną - jest dociążeniem przygodności na poziomie ontologicznym. Tyle kontekstowego wstępu. Przejdźmy już do indywidualnego losu - a raczej zapisu fragmentu wywiadu, który na niego naprowadza.

No mówię, no ja wiem, no... Urodziłam się też w rodzinie - ojciec gospodarz był. Ale też ciężkie warunki były, bo niby tam trochę ziemi było, a jeździł z handlem na Warszawę. Handlował, miał konie i w konie jeździł ze zbożem do Warszawy, z ziemniakami. Wyjechał na wieczór, na drugi dzień wracał. [...] Jeszcze dwóch braci było. No to też nasz było pięcioro. Też ciężko było, ciężko było, że, wie pan, że do szkoły mieliśmy to ja wiem, ile kilometrów? - z pięć kilometrów. Jak przyszła zima, śniegi, nie miałam butów skórzanych, tylko w gumowcach chodziłam. Nogi poodmrażałam, bo szło się tak do szkoły przez wszystkie tak, nie było ścieżki, tylko tak przez pola, śnieg do pasa. [...]. No, ojciec nie kupił butów, no trzeba było w gumowcach chodzić. [...] Tak ciężko było. No i co? Skończyłam siedem klas [...]. Miałam iść dalej do szkoły, zachorowałam, zachorowałam na wyrostek. Byłam operowana w Nowym Dworze na wyrostek. Po tym, dłuższy czas ten szew mi się otwierał, ropa wyciekała, nie goiło się, nie to, proszę pana. No i zrezygnowałam ze szkoły dalej. Bo już byłam, do Pomiechówka, dobra tam szkoła była, poskładane papiery, ale mówię - Ja już nie dam rady - bo tyle chorowałam, i to, i prze tego, nie poszłam. No i co? No i później, no, już jak się wychorowałam, wy tego, trafił się, trafił się narzeczony. Przychodził, przy tego. Wyszłam za mąż. [...] Mieszkaliśmy na razie też tam u ojca trochę, też nie było warunków, bo tam też tylko dwa mieszkania były i to. Ciężko było. No, później mąż wystarał się - była taka hodowla lisów. Wie pan? Te futerkowe, te lisy, co się zabijało, i te skórki na kołnierze, na czapki. Mąż przy tym pracował, no i nawet $\mathrm{i}$ ja pracowałam. Dostaliśmy mieszkanie tam na tej fermie, to taka 
była ferma. Tam pod, to było pod Pomiechówkiem, jak pan leciał. Taki tam fort jest, taki jak, o, ten zakręt i taki fort. I tam właśnie takie te domki były, tam żeśmy mieszkali kilka lat. Później to też to znowu, to tak samo, przenosili te całe fermy, te lisy do Świdra. Do Świdra. To tam w tym poszliśmy z tym, te całe kierownictwo, to wszystko, do tego Świdra. No tam też mieszkanie mieliśmy. Ale ciężko było, ciężko było. Bo już tak - i dzieci były, i to troje dzieci. Ciężko było. Niby tam zarobek był dobry, mąż dobrze zarabiał, ale to trzeba było wszystko z grosickiem i z koszyczkiem iść i kupić, też. I to, co zarobił, to prawie to się wszystko rozeszło, się wydało na to, po tego. No i co? No i tam waśnie byliśmy kilka lat. Potem co? Tutej teść mieszkał. Teść mieszkał z teściową, oczywiście, to myśmy tam z tego Świdra przyjeżdżali z mężem tutej na wieś. Zawsze to coś tam, a to się kaczkę przywiozło, a to parę jajek, a to to, tak troszkę, żeby było lżej, po tego. No i co? I proszę pana, później teściowa zmarła. [...] Jechała w konia na truskawki - to było tak w lipcu, jak truskawki są - do siostry, tam daleko też, tam na następną tam aż, het, het [...] było gorąco, że jakoś słabo jej się zrobiło i na tym wozie tak fiknęła, i życie skończyła. [...] No i tak teściowe pochowaliśmy, po tego. Dziadek potem co, żebyśmy z tego Świdra tutej przyszli, bo jak on sam będzie? Jak on sam będzie po tego, no? - Nic - mówi - tylko wy przyjdźcie. [...] No i mówi - To wy będziecie chodzić całe życie tam w tym świecie i to tu przyjdźcie. Będziecie mieli tu kawałek tej ziemi, to, pójdzie do pracy, trochę sobie przechowacie coś, przy tego. No, i wie pan, że ja to swój los opłakałam. Opłakałam zawczasu, nie chciałam tam z tego Świdra przyjść. Płakałam, mówię - Ty idź, a ja zostanę tam z dziećmi - pracowałam - I będę sobie - mówię - żyła mieszkania były, wszystko - będę żyła. Troje dzieci było. - Nie, nie, nie. Koniecznie po tego. [...] Płakałam, płakałam, ale no już przyszłam. No bo jak? Rozejść się, róż/ tego - przyszłam. Przyszliśmy po tego/ to, proszę pana, było w 1969 roku, jak żeśmy tutej przyszli. W 1972 roku mąż zginął. To jest dwa lata - trzy, tak? [...] Proszę pana, mąż poszedł do pracy, bo ciężko było, tu dziadek był z nami. Ciężko było z tej gospodarki się utrzymać. A jeszcze światła nie było tutej, dopiero przy nas światło tu zakładali. [...] Nie było studni. Woda, tam dalej taki jest stawek za tym lasem, tam był taki stawek, żeśmy wodę wozili w konia, po tego. No co? No później no trzeba studnię znowuż zrobić. [...] Mąż z pracy wracał, a pracował tu w Nasielsku. W Nasielsku, to jakieś cztery kilometry. I proszę pana, tyle lat jeździł na motorze i przejeżdżaliśmy z tego Świdra, i nie było wypadku, nie to. A tutej pieszo wracał z tej pracy [...] i szedł tymi torami.[...] Leciał 
pociąg na Warszawę i z Warszawy. Leciał ten, co leciał z Warszawy; on widział, że te światła na niego i to, i przechodził na drugi tor. A ten drugi gwizdał, gwizdał, a ten huk jego ogłuszył, że on nie słyszał, nie to, a była jeszcze wtedy taka silna mgła - 22 luty - silna mgła, że nic nie było widać. Nic nie było widać, no i ten drugi palnął męża. I leżał w torach, głowa cała rozbita na/ o szyny, o tego, no i co? No i co? Jak tutej potem sąsiedzi dali mnie znać, że to, że mąż nie żyje, no to... A ja już tak przeczuwałam. Ja już tak przeczuwałam, bo zawsze jak przychodził, nim przyszedł z pracy, to ja już tu tak oporządziłam, co było, tam te krówki po tego, no i z dziećmi już sobie robimy kolację, po tego, i czekamy, że przyjdzie z pracy. [...] Zrobiło się już i ciemno, i to, i nie ma męża, no nie ma męża, nie przychodzi, nie tego. Naraz wieczorem ktoś stuka we drzwi. [...] Otwórz. A ja mówię - Kto tam? - Otwórz. Mówię - Nie wiem, kto. A kto - mówię - jest? Mój ojciec przyszedł, jakoś najpierw ktoś dał znać do ojca, żeby ojciec tu przyszedł do nas, że mąż już nie żył. Już mąż nie żył, już go tam z tych torów od razu tam na posterunek zabrali z tego. Ojciec przyszedł, no i tak wszedł do mieszkania. A dzieci już na łóżku spały, a ten syn, najmłodszy, wtedy miał sześć lat, najmłodszy. Córka najstarsza miała piętnaście lat, a syn, najmłodszy, jeszcze nie chodził do pierwszej klasy. Tak pochylił się nad nim, ale mówi tak - A gdzie ojciec? A ja mówię - No jeszcze z pracy nie wrócił. A tatuś nie wie, może tam gdzieś po tego? Nachylił się nad tym synem - Ojciec już nie żyje. [...] Krzyk się zrobił z tego, dzieci po tego, wszystko wystraszone, wy tego. Mąż już nie żyje, po tego, no.

No i co? No i tak zostałam później z tymi dziećmi. Trochę gospodarzyłam, dzieci się uczyły, dostawały rentę. (płacz) / No i jakoś, o, jeszcze ojciec żył i dwóch braci miałam. Przychodzili, mnie tu trochę pomagali. Tam z Cegielni bracia przyjeżdżali, a to czy w żniwa, ściąć zboże, czy zaorać, czy co, no to pomagali mnie, po tego. No i jako tako tak gospodarzyłam. Potem najstarsza córka skończyła technikum w Mławie, chodziła do Mławy, takie technikum ogólnospożywcze. Skończyła, przy tego. [...] No, za jakiś czas znowuż tamta druga skończyła też. Do Warszawy jeździła do szkoły w zakładach mięsnych na Służewcu, może pan zna? [...] Później znowu, tak samo, no trafił się chłopak, po tego, za mąż, za mąż. Wyszła za mąż, po tego. Pobudowała się, o, ja tu jej działkę dałam, pobudowała się tu koło mnie. No to później został mi już tylko ten syn. [...] Syn szkołę skończył też, jako mechanik samochodowy, do Nowego Dworu chodził. [...] Poszedł do pracy do Warszawy. [...] A no, odpisałam mu te gospodarkę, te ziemię, bo już, ja już nie miałam siły gospodarzyć, już byłam, już 
trzy razy miałam operacje robione w szpitalu. I już mówię, skończyłam 55 lat, odpisałam mu te gospodarkę całe, mówię - Masz, gospodarz. A ja już, mnie wystarczy, ja już się napracowałam, mnie wystarczy. [...]

No i tak, proszę pana, i tak mnie było ciężko, tak mnie było ciężko, że ze zdrowia siadłam. I dzisiaj i kręgosłup boli, i nogi bolą, żylaki miałam operowane też i chodzę. I chodzę - nie siedzę - co mogę. I drzewa sobie natnę, chodzę, tu o, lasek jest, przyniosę drzewa, sobie natnę, naszykuję. [...] I węgla sobie kupię. Dostałam te emeryturę, te parę groszy mnie wystarcza, ale jeszcze, dużo jeszcze pomagam. I tym dzieciom dam, i na światło daję, bo są duże rachunki, oni tam bez przerwy świecą i dzieci - i komputer, i telewizor, i to. Bo ja to tam sobie, tak o, posiedzę, nie świecę. I pomagam i tym dzieciom, i mówię - człowiek od młodości do starości, nie było letko i nie jest letko, i co bym sobie coś mogła po tego, to nic nie mogę, tylko co to; to wnuczkom pomogę, czy na jakieś tam coś zawsze parę groszy dam i to. No i taki mój żywot. Taki mój żywot był - od młodości do starości. No. Mąż miał 39 lat, jak go, ten wypadek, a ja 34 lata. (płacz) / No. I tyle lat... i tyle lat się mordowałam, poświęciłam się dla dzieci. No, ale trudno już, mówię, aby tylko te zdrowie pan Bóg dawał, to tak sobie sama jeszcze wszystko zrobię, i sprzątnę, i to, i ciepło mam, i jeszcze ugotuję sobie, i kupię, i to. I jakoś się wywiązuję ze wszystkiego i... No. I tak, proszę pana. No. Taki był żywot od młodości i ciężko do starości. Tak.

Wbrew interpretacyjnym zwyczajom, a zwłaszcza wbrew regułom rozmaitych „analiz strukturalnych" właściwych dla socjologii biograficznej zdecydowałem się na przywołanie niemal w całości dłuższego, zwartego fragmentu wypowiedzi mojej Rozmówczyni (wykropkowane nawiasy wskazują jedynie na usunięcie powtórzeń, a w paru przypadkach krótkich, jedno-, dwuzdaniowych rozwinięć wprowadzonego wątku). Jest to fragment podstawowy i kluczowy. Podstawowy, ponieważ ogniskuje się wokół najważniejszych doświadczeń życiowych pani Stefanii - w szczególności wypadku jej męża. Te doświadczenia wyznaczyły ramy jej biografii - jeśli nie jej grube mury. Cała „reszta” życia oglądana retrospektywnie i dosyć szczegółowo opowiadana podczas naszego spotkania, jakby mieściła się wewnątrz tych ram - jakby rozgrywała się wewnątrz tych murów, choć fizycznie przecież w dużej mierze na otwartej przestrzeni, pod gołym niebem. Kluczowy - gdyż ujawnia wysiłek nadawania tym doświadczeniom, a z nimi całemu życiu, spójnego biograficznego sensu. Ten wysiłek nazwałbym właśnie hermeneutyką losu. Można dodać - by odróżnić ją od dalszych jego interpretacji, od interpretacji drugiego 
stopnia - hermeneutyką podstawową czy elementarną, ponieważ dotyczącą własnego życia, własnego losu. I zarazem powszechną, gdyż dotyczącą każdego, choć szczęśliwie nie każdy doświadcza losu tak hiobowego, a wielu pewnie nawet nie zauważa, że ich życie to jakiś „los”. Zresztą i na poziomie hermeneutyki drugiego stopnia, mowa raczej o podmiotowym sprawstwie i jego strukturalnych ograniczeniach ${ }^{13}$. Względnie - co już bliżej - o ryzyku, a więc niejako niechcianym przypadku, który staje się stałym towarzyszem mieszkańców późnej nowoczesności ${ }^{14}$. Wprost o losie mówi dziś mało kto choć są istotne wyjątki ${ }^{15}$.

A jednak potrzeba, jeśli nie zwyczajna konieczność, usensownienia własnego życia, zobaczenia wielości jego rozproszonych przypadków jako swojego niepodmienialnego losu wydaje się fundamentalnie, by nie powiedzieć, definicyjnie, ludzka. Przynajmniej dla tej kultury „człowieczeństwa”, w jakiej aktualnie żyjemy - rozpiętej między jego praktyczną absolutyzacją z jednej, a teoretyczną negacją z drugiej strony.

Zadoścuczynienie tej potrzebie, sprostanie tej konieczności wymaga nieraz, jak w analizowanym tutaj przypadku, nadludzkich sił. Zwłaszcza gdy pozostaje pracą niezakończoną, bo i niedającą się zakończyć - a więc wymagającą ciągle sił nowych. Mamy tu przecież świadectwo zmagań z nadawaniem sensu - a nie świadectwo jego ostatecznego nadania. Zapis dźwiękowy ujawnia to znacznie wyraźniej niż transkrypcja. Kilkukrotnie powracający płacz Rozmówczyni, wywołany wspomnieniem tragicznej śmierci męża (w cytowanym fragmencie dwukrotnie odnotowany, ale będący bezsłownym refrenem całej tej opowieści), wprost pokazuje niemożność domknięcia owego biograficznego sensu. Ten płacz można czytać psychologicznie jako świadectwo traumy. Można go też jednak interpretować antropologicznie (filozoficzno-antropologicznie) jako reakcję graniczną na obezwładniający

13 W teorii socjologicznej wybrzmiewa to dziś najwyraźniej w pracach Margaret S. Archer - także tej jedynej przetłumaczonej na język polski: Człowieczeństwo. Problem sprawstwa, przeł. A. Dziuban, Nomos, Kraków 2013; Zob. także: A. Mrozowicki, O. Kowalczyk, I. Szlachcicowa Sprawstwo. Teorie, metody, badania empiryczne w naukach społecznych, Nomos, Kraków 2013.

14 U. Beck Społeczeństwo ryzyka. W drodze do innej nowoczesności, przeł. S. Cieśla, Scholar, Warszawa 2004.

Jednym z nich jest z pewnością cytowany już wcześniej, zmarły w 2016, Odo Marquard, którego nazwać można (także) filozofem ludzkiej kontyngencji - a więc przygodności i zarazem losowości w wyżej zarysowanym znaczeniu. W polskiej literaturze filozoficznej jego twórczość omawia: S. Czerniak Kontyngencja, Tożsamość, Człowiek - studia z antropologii filozoficznej XX wieku, Wydawnictwo IFiS PAN, Warszawa 2006. 
splot przypadków, który wytrąca człowieka z poczucia kierowania własnym życiem. Skoro nic zrobić się nie da(ło), pozostaje zapłakać nad swoim losem i w tym płaczu na chwilę uwolnić się od jego przemożnej presji' ${ }^{16}$.

Ale to zaledwie pierwsze, jakby najbardziej zewnętrzne rozpoznanie losowości tego świadectwa mówionego. Wewnątrz, na poziomie konkretnych decyzji i zdarzeń przywołanych przez Rozmówczynię, otrzymujemy wgląd w szczegółowe momenty biograficznej przygodności. I są to przygodności, czy bardziej uczenie: kontyngencje, dwojakiego rodzaju. Zarówno kontyngencje losowe, jak i kontyngencje wyboru. Chodzi więc zarówno o zdarzenia, na które nie mamy wpływu, które spadają na nas z zewnątrz, jak i o własne wybory dokonane z puli dostępnych i możliwych w danych okolicznościach ${ }^{17}$. Ten krótki fragment wywiadu pokazuje także, jak mocno jedne splecione są z drugimi. Wypadek kolejowy spada na Narratorkę jak „grom z jasnego nieba", jest jakimś okrutnym wymykiem losu z codziennej rutyny. Ale warunkiem możliwości tej sytuacji są wcześniejsze decyzje życiowe młodych małżonków - podjęte wszak pod presją życiowych okoliczności albo po prostu rodzinnej namowy. I jeszcze ten dramatyczny obraz przeczucia własnego nieszczęścia. Czy historycznie prawdziwy? Nie wiemy z pewnością, ale możemy chyba przyjąć, że tamtej decyzji o przeprowadzce towarzyszyły autentyczne niepewność i lęk. I że wobec losowych zdarzeń, które po niej nastąpiły, nabrały one ciężaru złowróżbnej przepowiedni - choć nie słowami wyrażonej, a płaczem. Taki splot obu rodzajów przygodności rodzi filozoficzne i egzystencjalne pytania o przyczynowość biograficznych przypadków i kontrolę nad własnym życiem. Odpowiedzi teoretyczne mogą być rozmaite, praktyczne pozostać muszą jedynie spekulacją na temat niezrealizowanych, a biograficznie dostępnych opcji wyboru, które „uchroniłyby” od zaznanych nieszczęść. Tak niewiele trzeba (było), by uciec od wyroków losu.

A może losu wcale nie da się tak prosto oszukać - a przynajmniej nie da się oszukać do końca? I nie chodzi tylko o to, że nieszczęśliwe, także tragiczne wypadki mogą się przydarzyć wszędzie i każdemu. Na tym wszak ich losowość czy przygodność polega, że przecinać potrafią wszelkie założone

16 To nawiązanie do Hemutha Plessnera interpretacji płaczu (i śmiechu) jako zachowań granicznych, tegoż Śmiech i płacz. Badania nad granicami ludzkiego zachowania, przeł. A. Zwolińska, Z. Nerczuk, Antyk, Kęty 2004.

17 To rozróżnienie pojawia u Odo Marquarda jako kontyngencja losowa i kontyngencja wyboru. Interpretuje je wnikliwie - także w odniesieniu do teorii socjologicznej Pierre'a Bourdieu Stanisław Czerniak w cytowanej wyżej pracy. 
ciągi zdarzeń, wszelkie utrwalone schematy i rutyny działań. Choć i one nie są bezprzyczynowe - jakoś musimy je wszak sobie objaśnić, zracjonalizować, jakoś „zabezpieczyć się na przyszłość”. Ale chodzi o coś jeszcze innego, o społeczno-historyczny wymiar biograficznej losowości. Dotychczasowa interpretacja jakby go omijała, przeskakując niejako na poziom wyżej, powiedzmy antropologiczno-egzystencjalny. Mamy tu jednak nie tylko przypadki, które - potencjalnie - przydarzyć się mogą każdemu, ale też bardzo wyrazisty opis polskiej biedy. Tak po prostu. Piesza droga do szkoły przez pole w kaloszach jest niemal wzorcowym, rozpoznawczym znakiem pewnego wariantu ludzkiego losu - historycznie i społecznie osadzonego. Podobnie jak choroba, która przerywa dalszą naukę. Wszystkie dzieci chorują, ale konsekwencje tych chorób są społecznie, by nie powiedzieć po prostu: klasowo, nierówno rozłożone. I tak dalej, i dalej - widać przecież nawet w tym krótkim wyimku wyraźny odcisk gęstej sieci strukturalnych ograniczeń, które wyznaczają zakres możliwych życiowych wyborów - rodziców Narratorki, jej samej, jej męża, dzieci, dalszych krewnych... - i skłaniają do pytań o społeczne, strukturalne determinanty takiego jej (i ich) losu. A jeśli nie determinanty, to co najmniej ich warunki prawdopodobieństwa. I nie chodzi tylko o samo losowe zdarzenie - tj. w pewnym stopniu niezależne od społecznego usytuowania (każda żona może stracić męża w tragicznym wypadku, nawet jeśli okoliczności wypadków menadżerów i robotników mogą się statystycznie znacząco różnić), co o społeczne, kulturowe i ekonomiczne zasoby, niech będzie: kapitał, który można uruchomić w momencie kryzysu, by przynajmniej złagodzić jego długofalowe skutki. Wtedy, być może, mimo doświadczonej życiowej tragedii, w biograficznej narracji nie padnie zdanie o ciężkim żywocie „od młodości do starości”.

Te perspektywy - nazwane tu antropologiczno-egzystencjalną i socjologiczno-historyczną, nie muszą być traktowane jako rozłączne, a tym bardziej zwalczające się propozycje interpretacyjne. Nawet jeśli odwołują się do innego zaplecza teoretycznego, to zastosowane analitycznie wobec tej samej autobiograficznej ekspresji (celowo nie piszę: wobec autobiograficznego tekstu) pozwalają wydobyć różne jej równoległe sensy. Więcej, myślę, że spojrzenie na biografię przez pryzmat przypadku i losu daje szansę ich każdorazowego krzyżowania i uzgadniania, może nawet przezwyciężenia redukcjonizmów interpretacyjnych każdego z tych podejść z osobna. To po prostu patrzenie na ludzkie doświadczenia, a ściślej - na doświadczenia życiowe konkretnego człowieka, pod różnym kątem jednocześnie i dostrzeganie, że egzystencjalne tragedie (ale też komedie) wypełniające indywidualne losy, uwikłane są 
w strukturalne realia - i że jedne do drugich sprowadzić się nie dają, a w każdym razie może nie warto tego robić.

To niejako poziom rzeczywistości - raz widzianej egzystencjalnie, raz socjologicznie i historycznie. Ale jest jeszcze poziom tekstu - i całej poza- oraz wewnątrztekstowej ekspresji nieuchwyconej słowami, ale obecnej przecież stale w historii mówionej. Tu też mamy potencjalne napięcie interpretacyjne między analizą jawnych i ukrytych "struktur” - a poszukiwaniem znaczeń i sensów autobiograficznej wypowiedzi. Może i ono jest do przekroczenia, jeśli zobaczymy - a może raczej poczujemy - że za migotliwym parawanem znaczących toczą się ludzkie dramaty, ludzkie losy. Bez tego parawanu w ogóle się o nich nie dowiemy, niewiele z nich zrozumiemy i nic sobie nawzajem na ich temat nie zakomunikujemy. Ale dopiero w prześwitach tej gęstej sieci znaków dostrzec możemy egzystencjalną stawkę porozumienia, o jaką w tej komunikacji chodzi. Semiotyczna rozbiórka tu nie wystarczy, choć może być pomocna i poznawczo cenna - także dla sprawy głównej, tj. rozpoznania egzystencjalnego ciężaru przywoływanych doświadczeń. W tym też sensie doświadczenie naszych rozmówców jest w historii mówionej przed-tekstem, który jej zaświadcza, ale raczej przez naprowadzenie niż przez reprezentację. Zarzuty niedoskonałości albo i niemożliwości tej reprezentacji są w tej perspektywie jakby nieadekwatne.

Ale przedtekstowość doświadczenia znaczy w historii mówionej coś jeszcze. Wizualny, dźwiękowy, a potem zwykle tekstowy zapis jest przecież efektem bezpośredniej międzyludzkiej komunikacji, wzajemnego zaufania, jakiegoś elementarnego otwarcia na Innego. To nie tylko komunikacja słowna, ale sytuacja współobecności, dialogicznego współbycia. Sytuacja dramatyczna ${ }^{18}$ - w źródłowym, teatralnym, a dziś powiedzielibyśmy może: performatywnym rozumieniu tego słowa - która zostawia w nas trwały ślad, która nas zmienia. Nie tylko w tym sensie, że dowiadujemy się czegoś nowego, że znamy czyjąś historię. Także w tym, że na historię własną, na własną historyczną przygodność i na przygodność naszych życiowych przypadków spoglądamy nieco inaczej. Choćby przez chwilę po takim spotkaniu, zanim nie wrócimy w bezpieczne koleiny własnego losu. Albo na jego wspomnienie, które na moment z tych kolein nas jeszcze wytrąci. Zapis audio, wideo, niekiedy także tekst - na sceny tego między/ludzkiego dramatu potrafi niekiedy celnie naprowadzić nie tylko jego aktorów, ale i widzów.

18 Odwołuję się tu do wątków Tischnerowskiej filozofii dialogu jako filozofii dramatu: J. Tischner Filozofia dramatu, Znak, Kraków 2012. 
Powtarzam tu słowa „niekiedy”, ,nieraz”, „,zasem”, mówię też: „przydarza się", ,zdarza”, „bywa”..., ponieważ nie opisuję historii mówionej takiej, jaka zwykle jest. Ale nie o statystyki częstotliwości tu przecież idzie ani nawet o jakiś jej wyróżniony typ, ale o potencjalność, która w niej tkwi. Warto, myślę, być na nią otwartym - zarówno we własnej praktyce historii mówionej, jak i w stylu jej odbioru' ${ }^{19}$. Po co taka komplikacja? Po to m.in., by nie tylko gromadzić dane czy źródła, a nawet zapisywać czyjeś doświadczenia i biografie, ale by uprawiać humanistykę - tu w wariancie hermeneutyki najbardziej zwyczajnego losu. Losu Innego i losu własnego.

\section{Abstract}

\section{Piotr Filipkowski}

INSTITUTE OF PHILOSOPHY AND SOCIOLOGY OFTHE POLISH ACADEMY OF SCIENCES

Oral History as a Hermeneutics of Fate: Pretextual Experience

Filipkowski offers a preliminary proposal to inscribe oral history into broader philosophical contexts. Oral history is understood as a practice in the humanities that is based on the pretextual experience of the human encounter, which in turn represents a precondition for any dialogue aiming to understand the Other. Filipkowski brings oral history to bear on the hermeneutic tradition and on reflections on coincidence and accidentality as developed in the field of philosophical anthropology. The notions of coincidence and accidentality are inextricably inscribed into (human) existence. They are used to analyse a specific biography, allowing us to look at it from the perspective of fate, while narrations about it can be seen as meaning-making articulations.

\section{Keywords}

oral history, biography, (pretextual) experience, narration, coincidence, accidentality, existence, fate

19 Nawiązuję tu do literaturoznawczej koncepcji stylów odbioru rozwijanej przez Michała Głowińskiego. Zob. tegoż Style Odbioru. Szkice o komunikacji literackiej, Wydawnictwo Literackie, Kraków 1977. 